\title{
Studies of the influence of uniaxial pressure on the electric behaviour of $\mathrm{Li}_{0.015} \mathrm{Na}_{0.985} \mathrm{NbO}_{3}$ ceramics
}

\author{
Śmiga W. and Garbarz-Glos B.
}

Institute of Physics, Pedagogical University, ul. Podchorążych 2, Kraków, Poland, e-mail: w.smiga@gmail.com

Received: 09.09.2012

\begin{abstract}
Lead-free ceramics $\mathrm{Li}_{0.015} \mathrm{Na}_{0.985} \mathrm{NbO}_{3}$ are synthesised using a conventional solid-state process. A single-phase perovskite ceramic structure is identified with an X-ray powder diffraction technique. An energy-dispersive X-ray spectroscopy analysis performed for individual grains of our sample shows a fairly homogeneous distribution of all the elements throughout the grains. The dielectric permittivity $\varepsilon$ and the loss tangent $\tan \delta$ are measured under uniaxial pressure. With increasing pressure, the peak in the $\varepsilon(T)$ curve decreases, becomes diffused, and finally shifts towards lower temperatures $T$. The value $\tan \delta$ increases with increasing uniaxial pressure, while its local maximum also shifts towards lower temperatures.
\end{abstract}

Keywords: $\mathrm{NaNbO}_{3}-\mathrm{LiNbO}_{3}$ solid solutions, antiferroelectrics, dielectric properties

PACS: 77.80.-e, 77.22.d, 77.65j

UDC: 536,537

\section{Introduction}

A sodium-lithium niobate solid solution is based on a mixture of $\mathrm{NaNbO}_{3}$ and $\mathrm{LiNbO}_{3}$. The sodium niobate $(\mathrm{NN})$ has a perovskite-type structure and represents one of the best-investigated materials of all the niobates [1-3]. It is antiferroelectric at the temperatures ranging from 233 to $644 \mathrm{~K}$, with an orthorhombic structure in a rhombic orientation. The NN belongs to a ferroelectric state with a rhombohedral structure below $233 \mathrm{~K}$. An orthorhombic symmetry in a parallel orientation is observed for this compound at $644-848 \mathrm{~K}$ and it becomes cubic above $914 \mathrm{~K}$. From the structural point of view, the pure NN undergoes six different phase transitions at the temperatures $233,644,753,793,848$ and $914 \mathrm{~K}$ (see [2-4]). Finally, an antiferroelectric-to-paraelectric phase transition takes place at $644 \mathrm{~K}$ [4-9].

A polycrystalline lithium niobate ( $\mathrm{LN}$ ) belongs to ilmenite-type materials. $\mathrm{LiNbO}_{3}$ possesses ferroelectric properties and undergoes a ferroelectric-to-paraelectric phase transition at the temperature of about $1402 \mathrm{~K}$, becoming cubic at this point. At the room temperature it belongs to a rhombohedral system [10]. Because of its good optical and piezoelectric properties, the LN has found wide applications in electronics and nonlinear optics [11-13]. The system $\mathrm{NaNbO}_{3}-\mathrm{LiNbO}_{3}$ $\left(\mathrm{Li}_{\mathrm{x}} \mathrm{Na}_{1-\mathrm{x}} \mathrm{NbO}_{3}\right)$ is also interesting, especially in the case of high lithium concentrations. The compounds $\mathrm{Li}_{\mathrm{x}} \mathrm{Na}_{1-\mathrm{x}} \mathrm{NbO}_{3}$ are antiferoelectric at the room temperature at $x<0.02$ and ferroelectric at higher contents $x$ [14].

${ }^{*}$ The materials of this work have been reported at the $2^{\text {nd }}$ Ukrainian-Polish-Lithuanian Meeting on Ferroelectrics Physics (9-13 September 2012, Lviv, Ukraine).

Ukr. J. Phys. Opt. 2012, V13, Suppl.3 
Reports on the optical properties of $\mathrm{Na}_{0.98} \mathrm{Li}_{0.02} \mathrm{NbO}_{3}$ single crystal have described five phase transitions between 163 and $940 \mathrm{~K}$, with the Curie temperature found around $640 \mathrm{~K}$ [4, 15]. Using optical techniques and observing thermal evolution of optical birefringence in the single crystals with $x=0.02$, an additional ferroelastic structural phase transition has been found inside the paraelectric phase $[13,14]$. According to these results, the above compound should be ferroelectric at the temperature of about $940 \mathrm{~K}$ [15]. Above this point, the compound acquires a prototype cubic phase $m 3 m$.

As for the solid solutions $\mathrm{Li}_{\mathrm{x}} \mathrm{Na}_{1-\mathrm{x}} \mathrm{NbO}_{3}$, they have to be good candidates for fabricating piezoelectric and pyroelectric components for different high-temperature purposes [16-21]. The aim of this work is to investigate the influence of uniaxial pressure on the temperature changes seen in the dielectric permittivity $\varepsilon$, the dielectric loss $\tan \delta$ and the electric conductivity $\sigma$ of $\mathrm{Li}_{0.015} \mathrm{Na}_{0.985} \mathrm{NbO}_{3}$ ceramic samples.

\section{Experiment and discussion}

\subsection{Sample preparation}

$\mathrm{Li}_{0.015} \mathrm{Na}_{0.985} \mathrm{NbO}_{3}$ ceramic samples were prepared at the Institute of Solid State Physics, University of Latvia (Riga). A conventional method was applied. The samples were synthesised from an analytically pure niobium pentoxide $\mathrm{Nb}_{2} \mathrm{O}_{5}$, sodium carbonate $\mathrm{Na}_{2} \mathrm{CO}_{3}$, and lithium carbonate $\mathrm{Li}_{2} \mathrm{CO}_{3}$. The reagents were wet stirred for $24 \mathrm{~h}$ with an ethanol addition. After filtrating the material was synthesised at $1173 \mathrm{~K}$. The samples were disintegrated, wet ground for $24 \mathrm{~h}$, pressed under the pressure of $15 \mathrm{MPa}$, and then sintered. The sintering temperature for $\mathrm{Li}_{0.015} \mathrm{Na}_{0.985} \mathrm{NbO}_{3}$ was $1433 \mathrm{~K}$ and the time of sintering was $4 \mathrm{~h}$.

\subsection{X-ray measurements}

The X-ray measurements for $\mathrm{Li}_{0.015} \mathrm{Na}_{0.985} \mathrm{NbO}_{3}$ were performed by means of a Seifert equipment $\mathrm{XRD} 7$ with horizontal goniometer, making use of the filtering $\mathrm{Cu}_{\mathrm{K} \alpha}$ radiation. The phase analysis was carried out using a RayfleX-Analysis Programme and JCPDC-ICDD cards. The sample of a perovskite structure was single-phase. The X-ray measurements showed that, at the room temperature, the compound was characterised by the lattice constants $a=0.5479 \mathrm{~nm}, b=1.5523 \mathrm{~nm}$ and $c=0.5559 \mathrm{~nm}$, and the elementary cell volume $V=0.48142 \mathrm{~nm}^{3}$. The results obtained testified that the lattice parameters of $\mathrm{Li}_{0.015} \mathrm{Na}_{0.985} \mathrm{NbO}_{3}$ decreased when compared with the pure $\mathrm{NN}$.

\subsection{Microstructure investigation}

The microstructure of the sintered ceramics was investigated on fractures and polished sections. This was carried out using an electron scanning microscope Hitachi S4700 with a field emission, and a micro-analysing system Noran-Vantage located at the Biology and Geology Science Scanning Laboratory, Jagiellonian University. Fig. 1 shows the model diffraction patterns seen in the

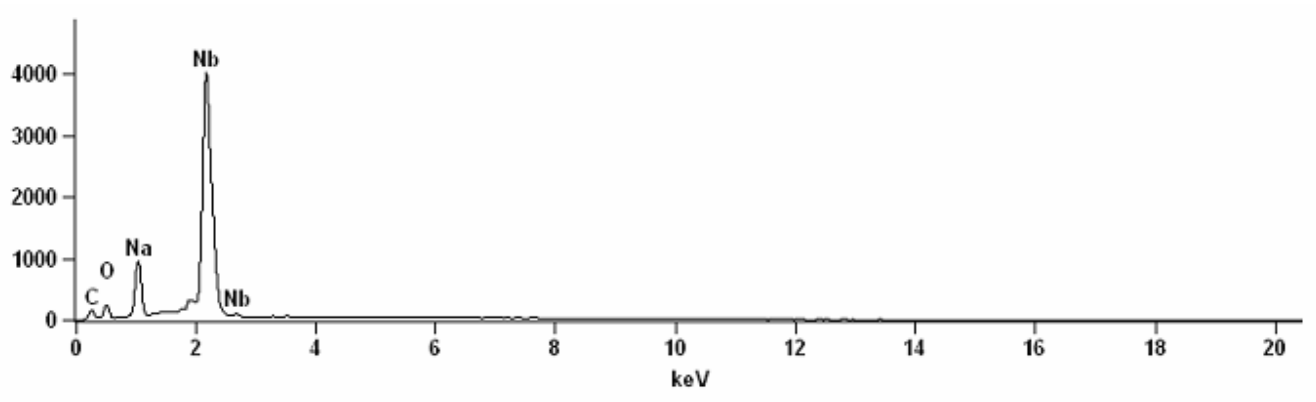

Fig. 1. Energy-dispersive $X$-ray spectroscopy analysis of $\mathrm{Li}_{0.015} \mathrm{Na}_{0.985} \mathrm{NbO}_{3}$. 
chosen micro-regions of surface of our $\mathrm{Li}_{0.015} \mathrm{Na}_{0.985} \mathrm{NbO}_{3}$ sample. No more than the expected elements can be seen in the diffraction patterns. The carbon sputtered on the surface of the sample during its preparation is also visible. The photographs of fractures of $\mathrm{Li}_{0.015} \mathrm{Na}_{0.985} \mathrm{NbO}_{3}$ performed with magnifications of $1000 \times$ and $5000 \times$ are shown in Fig. 2. The surface of the fracture goes along grains as well as along the boundaries between the grains. The fracture has a fragile character and a tendency to formation of crystalline structures can be observed in the grains.
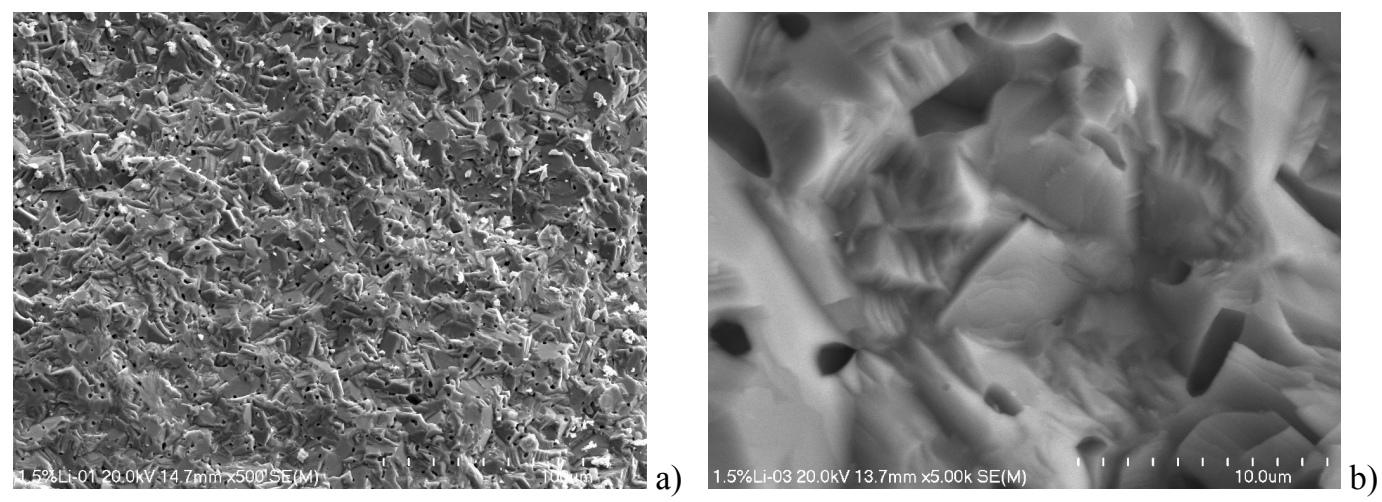

Fig. 2. Photograph of microstructure of the surface of $\mathrm{Li}_{0.015} \mathrm{Na}_{0.985} \mathrm{NbO}_{3}$ sample: panels (a) and (b) correspond to magnifications of $500 \times$ and $5000 \times$, respectively.

\subsection{Electrical properties}

Silver electrodes were fixed on both surfaces of the sintered pallets for the measurements of dielectric properties. Dielectric spectra as functions of temperature were measured with a BM595 RLGC-meter in the frequency range from $0.1 \mathrm{kHz}$ to $20 \mathrm{kHz}$, with the amplitude $2 \mathrm{kV} / \mathrm{m}$. A uniaxial load was applied parallel to the measuring electric field by means of a lever, with the weight ranging from 0 to $100 \mathrm{MPa}$. Prior to all the measurements, the samples were maintained at $800 \mathrm{~K}$ for $1 \mathrm{~h}$. A capacitance was recorded under a constant pressure for successive heating and cooling cycles at the rate of $100 \mathrm{~K} / \mathrm{h}$. The effect of uniaxial pressure on the dielectric permittivity $\varepsilon$ is presented in Fig. 3. As seen from Fig. 3, the $\varepsilon$ value decreases with increasing uniaxial pressure, especially at the temperature near the maximum. The shift of the phase transition is about $\approx 0.2 \mathrm{~K} / \mathrm{MPa}$. The $\varepsilon$ peak becomes more smeared, while the phase transition temperature $T_{m}$ decreases. A large thermal hysteresis is observed when the sample is heated and cooled.

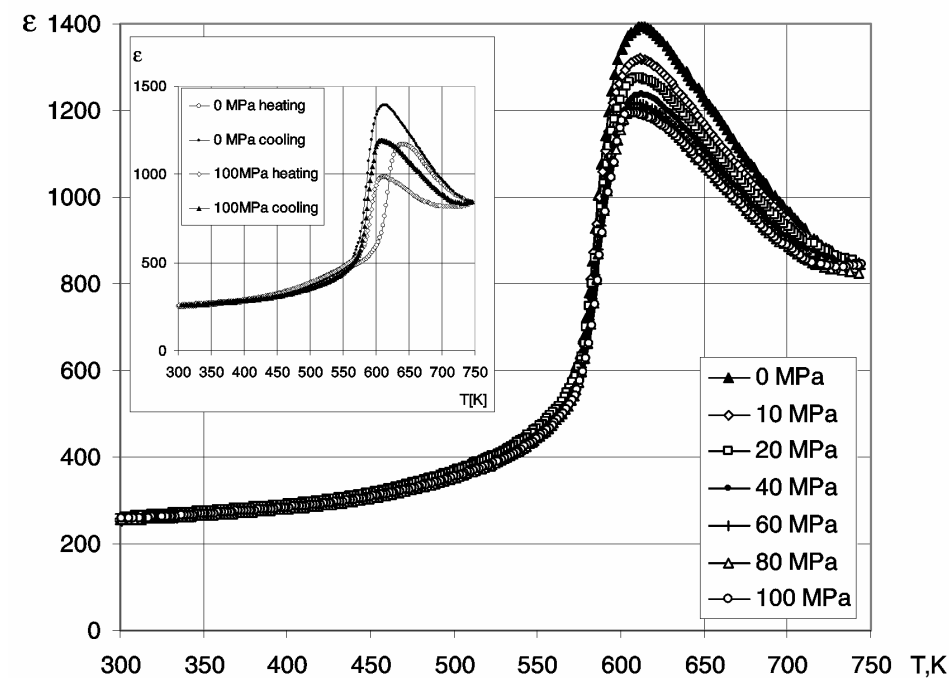

Fig. 3. Temperature dependence of the electric permittivity at various pressures on cooling process. The insert shows temperature dependence of dielectric permittivity in the heating and cooling modes at $p=0$ and $100 \mathrm{MPa}$.

Ukr. J. Phys. Opt. 2012, V13, Suppl.3 
Fig. 4 shows the temperature dependence of the dielectric loss $\tan \delta$ during the cooling run. The insert in Fig. 4a displays the temperature dependences of the dielectric loss $\tan \delta$ observed during heating and cooling at $p=0$ and $100 \mathrm{MPa}$. The minimal loss tangent value during the cooling process is seen at the pressure $p=0 \mathrm{MPa}$ and the temperature $580 \mathrm{~K}$. The tangent values increase with increasing pressure, and the local minimum of $\tan \delta$ shifts towards lower temperatures in both the heating and cooling modes.

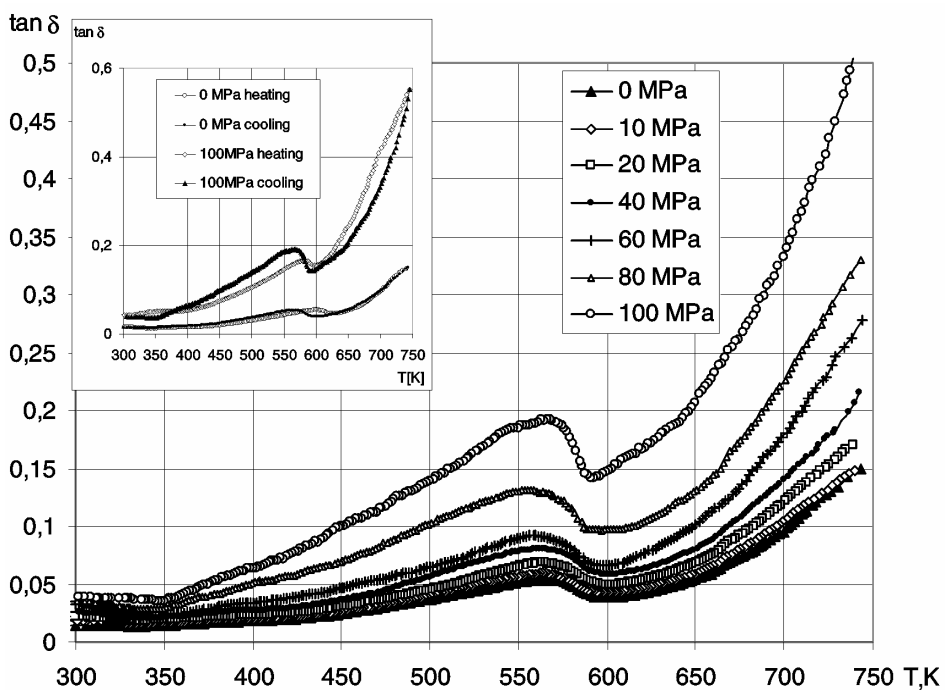

Fig. 4. Temperature dependences of dielectric loss $\tan \delta$ at different pressures on cooling. Insert shows temperature dependences of dielectric loss $\tan \delta$ in the both heating and cooling modes at $p=0$ and $100 \mathrm{MPa}$.

Fig. 5 shows the temperature dependences of the a. c. electric conductivity in the coordinates $\ln \sigma=f(1000 / T)$. The external conditions are given by the frequency $f=100 \mathrm{~Hz}$ and different pressures in the cooling run. The straight-line segments seen in Fig. 5 in the high-temperature region indicate that the electric conductivity can be described by the relation

$$
\sigma=\sigma_{0} e^{-\frac{E_{\alpha}}{k T}} .
$$

Using this formula, one can calculate the activation energy of the electric conductivity for the temperature region $590-670 \mathrm{~K}$. The corresponding parameters are as follows: $E_{\alpha 1}=0.18 \mathrm{eV}$, $E_{\alpha 2}=0.20 \mathrm{eV}$ and $E_{\alpha 3}=0.24 \mathrm{eV}$ for the pressures $p_{1}=0 \mathrm{MPa}, p_{2}=20 \mathrm{MPa}$ and $p_{3}=60 \mathrm{MPa}$, respectively. In the temperature range under investigation, the a. c. electric conductivity can be treated as the main dielectric loss component [22]. For the temperatures higher than the phase transition point $T_{m}$ (see Fig. 5), one can notice a straight component pointing out a thermally activated character of the a. c. conductivity. The mechanism of the electrical conduction changes with lowering temperature. With increasing uniaxial pressure, the electric conductivity increases in the whole temperature range.

The influence of the uniaxial pressure on the dielectric properties is similar to the influence of the constant electric field. The uniaxial pressure affects mainly the dynamics of domains. It retards the movement of domains and changes the nature of fastening of domains by structural defects. Therefore the uniaxial pressure makes the domains hard to reorientate and leads to decrease in the domain-orientated polarisation and the dielectric permittivity. It can also generate defects, causing additional internal stresses in the material [23]. The gradual shift of the phase transition point towards lower temperatures can be associated with the behaviour of polar regions $[24,25]$. The small micropolar regions are combined under pressure into macroregions that gener- 
ate a macroscopic spontaneous polarisation. They extend a ferroelectric state during heating and a paraelectric state during cooling. Moreover, a decrease of inter-ionic distances for the ceramic materials can lead to occurrence of two competitive mechanisms. The first one is an increase in the interaction constants, which leads to increasing $T_{m}$ and the second represents a decrease in the dipole moments. Since the latter leads to decreasing $T_{m}$ and is a predominant mechanism, $T_{m}$ decreases as in our material.

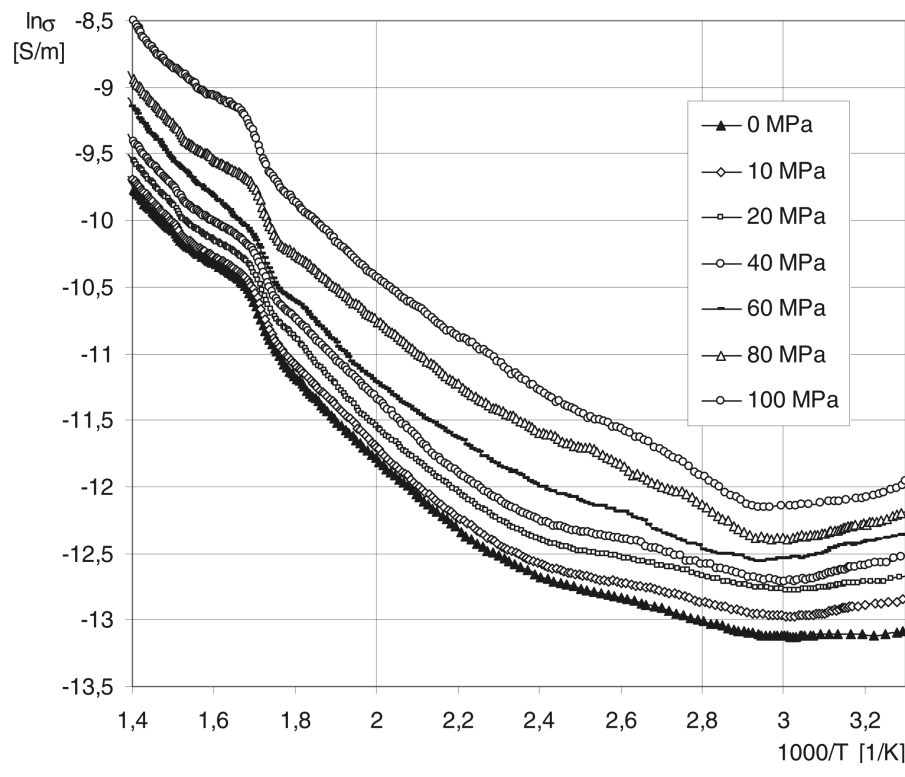

Fig. 5. Temperature dependences of a. c. electric conductivity $\ln \sigma=f(1000 / T)$ at the frequency $f=100 \mathrm{~Hz}$ and different pressures (a cooling mode).

\section{Summary}

The polycrystalline sample of $\mathrm{Li}_{0.015} \mathrm{Na}_{0.985} \mathrm{NbO}_{3}$ was obtained by means of a conventional ceramic technology. The synthesised material was examined with the X-ray diffraction and the scanning electron microscopy. The analysis of the X-ray diffraction pattern has testified formation of the single perovskite phase, with an orthorhombic structure at the room temperature. The microstructural investigations have revealed that the samples are perfectly sintered. They contain a little glassy phase and their grains are well shaped. The analysis of these experimental data has enabled us to conclude that the peak in the $\varepsilon(T)$ curve decreases with increasing pressure, becomes diffused, and shifts to lower temperatures. The loss tangent $\tan \delta$ increases with increasing uniaxial pressure, while its local maximum shifts towards lower temperatures. Finally, the present study shows that application of the uniaxial pressure has significant influences upon the dielectric properties of $\mathrm{Li}_{0.015} \mathrm{Na}_{0.985} \mathrm{NbO}_{3}$.

\section{References}

1. Glazer A M and Ishida K, 1973. Cation displacements and octahedral tilts in $\mathrm{NaNbO}_{3}$ Part I. Determination from x-ray difference reflections. Ferroelectrics. 6: 219-224.

2. Molak A, 1987. The influence of reduction in valency of $\mathrm{Nb}$ ions on the antiferroelectric phase transition in $\mathrm{NaNbO}_{3}$. Solid State Commun. 62: 413-417.

3. Miga S, Dec J and Pawełczyk M, 1996. Peculiarities of thermal switching in sodium niobate crystals. J. Phys. Condens. Matter. 8: 8413-8420.

4. Megaw H D, 1974. The seven phases of sodium niobate. Ferroelectrics. 7: 87-89. 
5. Kania A and Kwapuliński J, 1999. $\mathrm{Ag}_{1-\mathrm{x}} \mathrm{Na}_{\mathrm{x}} \mathrm{NbO}_{3}$ (ANN) solid solutions: from disorder antiferroelectric $\mathrm{AgNbO}_{3}$ to normal antiferroelectric $\mathrm{NaNbO}_{3}$. J. Phys. Condens. Matter. 11: 8933-8946.

6. Avogadro A, Bonera G, Borsa F and Rigamonti A, 1974. Static and dynamic properties of the structural phase transitions in $\mathrm{NaNbO}_{3}$. Phys. Rev. B 9: 3905-3920.

7. Raevskii I P, Reznichenko L A, Smotrakov V G, Eremkin V V, Malitskaya M A, Kuznetsova E M and Shilkina L A, 2000. A new phase transition in sodium niobate. Techn. Phys. Lett. 26: 744-746.

8. Koruza J, Tellier J, Malic B, Bobnar V and M. Kosec, 2010. Phase transitions of sodium niobate powder and ceramics prepared by solid state synthesis. J. Appl. Phys. 108: 113509.

9. Akhnazarova V V, Shilkina L A, Kravchenko O Yu and Reznichenko L A, 2011. Phase pattern of sodium niobate ceramics with different properties in the temperature range of 25 $700^{\circ} \mathrm{C}$. Crystallogr. Rep. 56: 5282-5288.

10. Abeoulleil M M and Leonberger F R, 1989. Waweguides in lithium niobate. J. Am. Ceram. Soc. 72: 1311-1321.

11. Miller R C, Boyd G D and Savage A, 1965. Nonlinear optical interactions in $\mathrm{LiNb0}_{3}$ without double refraction. Appl. Phys. Lett. 6: 77-80.

12. Weis R S and Gaylord T K, 1985. Lithium niobate: sumary of physical properties and structure. Appl. Phys. A. 37: 191-203.

13. Kip D, 1998. Photorefractive waveguides in oxide crystals: fabrication, properties, and application. Appl. Phys. B. 67: 131-150.

14. Sadel A, Von der Muhll R, Ravez J, Chaminade JP and Hagenmuler P, 1982. Synthese et etude des transitions de phases de ceramiques et de cristaux de composition $\mathrm{Li}_{0.02} \mathrm{Na}_{0.98} \mathrm{NbO}_{3}$. Solid State Commun. 44: 345-349.

15. Norbe MAL and Lanfredi S, 2003. Ferroelectric state analysis in grain boundary of $\mathrm{Na}_{0.85} \mathrm{Li}_{0.15} \mathrm{NbO}_{3}$ ceramic. J. Appl. Phys. 93: 5557-5562.

16. Sadel A, Van der Muhll R and Ravez J, 1983. Etude optique et coulpage ferroelectrique paraelectrique de cristaux de composition $\mathrm{Li}_{0.02} \mathrm{Na}_{0.98} \mathrm{NbO}_{3}$. Mat. Res. Bull. 18: 45-51.

17. Pardo L, Duran-Martin P, Mercurio IP, Nibou L and Jimenez B, 1997. Temperature behaviour of structural, dielectric and piezoelectric properties of sol-gel processed ceramics of the system $\mathrm{LiNbO}_{3}-\mathrm{NaNbO}_{3}$. J. Phys. Chem. Solids. 58: 1355-1339.

18. Jimenez R, Hungiria T, Castro A and Jimenez-Riobóo R, 2008. Phase transitions in $\mathrm{Na}_{1-\mathrm{x}} \mathrm{Li}_{\mathrm{x}} \mathrm{NbO}_{3}$ solid solution ceramics studied by a new pyroelectric current base method. $\mathrm{J}$. Phys. D.: Appl. Phys. 41: 065408.

19. Li G R, Yin Q R, Zheng L Y, Guo Y Y and Cao W W, 2008. Dielectric and piezoelectric properties of sodium lithium niobate $\mathrm{Na}_{1-\mathrm{x}} \mathrm{Li}_{\mathrm{X}} \mathrm{NbO}_{3}$ lead free ferroelectric ceramics. J. Electroceram. 21: 323-326.

20. Chaker C, El Gharbi W, Abdelmoula N, Simon A, Khemakechem H and Maglione M, 2011. $\mathrm{Na}_{1-\mathrm{x}} \mathrm{Li}_{\mathrm{x}} \mathrm{NbO}_{3}$ ceramics studied by X-ray diffraction, dielectric, pyroelectric, piezoelectric and Raman spectroscopy. J. Phys. Chem. Solids. 72: 1140-1146.

21. Jimenez B, Moure A, Castro A, Hungria T and Pardo L, 2004. Sodium-lithium niobate piezoceramics prepared by mechanochemical activation assisted methods. Boletin de la Sociedad Espanola de Ceramica y Vidrio. 43: 30-34.

22. Jonscher A K. Dielectric relaxation in solids. London: Chelsea Dielectric Press Ltd. (1983). 
23. Steiner O, Tagantser A K, Colla E L and Setter N, 1999. Uniaxial stress dependence of the permittivity electroceramics. J. Eur. Ceram. Soc. 19: 1243-1246.

24. Suchanicz J, Dambakalne M, Shebanovs L, Stenberg A, Garbarz-Glos B, Śmiga W and $\mathrm{Kuś} \mathrm{Cz}, 2003$. Effect of compressive stress on dielectric and ferroelectric properties of 0.25PSN-0.75PLuN ceramics. Ferroelectrics. 289: 53-61.

25. Suchanicz $\mathrm{J}$ and Kania A, 2008. Uniaxial pressure influence on dielectric properties of $\mathrm{Pb}\left(\mathrm{Zr}_{0.99} \mathrm{Ti}_{0.01}\right) \mathrm{O}_{3}$ single crystals. Phase Trans. 81: 1089-1093.

Śmiga W. and Garbarz-Glos B., 2012. Studies of the influence of uniaxial pressure on the electric behaviour of $\mathrm{Li}_{0.015} \mathrm{Na}_{0.985} \mathrm{NbO}_{3}$ ceramics. Ukr.J.Phys.Opt. 13, Suppl. 3: S27 - S33.

Анотація. Кераміку $\mathrm{Li}_{0.015} \mathrm{Na}_{0.985} \mathrm{NbO}_{3}$, що не містить свинию, синтезовано з використанням загальноприйнятого твердотільного процесу. Однофазну перовськитну структуру иісї кераміки ідентифіковано за Х-променевим порошковим дифракиійним методом. Аналіз окремих зерен, проведений за методом енергодисперсійної Х-спектроскопї̈, засвідчив досить однорідний розподіл усіх елементів у межах зерен. Діелектричну проникність в і тангенс кута втрат $\operatorname{tg} \delta$ досліджено під дією одновісного тиску. Зі зростанням тиску максимум залежності $\varepsilon(T)$ зменшується, стає розмитим $і$ змімується в область нижчих температур. Значення $\operatorname{tg} \delta$ зростає з підвищенням одновісного тиску, а його локальний максимум змішується у бік низьких температур. 